\title{
A Useful Method for Differential Evaluation of Anti-Inflammatory Effects Due to Cyclooxygenase and 5-Lipoxygenase Inhibitions in Mice
}

\author{
Katsumi Ishii ${ }^{1}$, Satoru Motoyoshi ${ }^{1}$, Joe Kawata ${ }^{1}$, Hiroyo Nakagawa ${ }^{2}$ and Kunihiko Takeyama' \\ 'Department of Pharmacology, Exploratory Research Laboratories, ${ }^{2}$ Drug Regulatory Affairs, Dainippon Pharmaceutical Co., Ltd., \\ 33-94 Enoki, Suita, Osaka 564, Japan \\ Received October 25, 1993 Accepted April 22, 1994
}

\begin{abstract}
This study was performed to establish a useful method for monitoring the effects of inhibitors of 5-lipoxygenase (5-LO) and/or cyclooxygenase (CO) and for differential evaluation of these inhibitors. After oral dosing, $\mathrm{CO}$ inhibitors such as indomethacin $(20-40 \mathrm{mg} / \mathrm{kg})$ and ketoprofen $(40-80$ $\mathrm{mg} / \mathrm{kg}$ ), zileuton (5-LO inhibitor, $20-80 \mathrm{mg} / \mathrm{kg}$ ) and MK886 (5-LO-activating-protein inhibitor, 640 $\mathrm{mg} / \mathrm{kg}$ ) potently suppressed arachidonic acid (AA, $0.25 \mathrm{mg}$ )-induced ear edema in mice. Methysergide (serotonin antagonist, $20 \mathrm{mg} / \mathrm{kg}$ ) showed a slight anti-edematous effect, while mepyramine $(160 \mathrm{mg} / \mathrm{kg}$ ) and bromelain $(320 \mathrm{mg} / \mathrm{kg})$ had no effect. The anti-edematous effects of indomethacin and ketoprofen were reduced by concomitant topical application of prostaglandin $\mathrm{E}_{2}\left(\mathrm{PGE}_{2}, 1 \mu \mathrm{g} / \mathrm{ear}\right)$, but not by concomitant intradermal application of leukotriene $\mathrm{C}_{4}\left(\mathrm{LTC}_{4}, 0.1 \mu \mathrm{g} / \mathrm{ear}\right)$. On the contrary, the anti-edematous effects of zileuton and MK886 were reduced by $\mathrm{LTC}_{4}$, but not by $\mathrm{PGE}_{2}$. Dual (5-LO and CO) inhibitors such as phenidone $(80-160 \mathrm{mg} / \mathrm{kg})$ and $\mathrm{BW} 755 \mathrm{C}(40-80 \mathrm{mg} / \mathrm{kg})$, which inhibited the biosynthesis of $\mathrm{LTB}_{4} 13-15$ times more potently than that of $\mathrm{PGE}_{2}$ in rat peritoneal exudate cells, also showed anti-edematous effects that were reduced by $\mathrm{LTC}_{4}$, but not by $\mathrm{PGE}_{2}$. These results suggest that the $\mathrm{AA}(0.25 \mathrm{mg})$-induced ear edema in mice is mainly mediated by LTs and PGs and is suitable for evaluating inhibitors of 5-LO and/or $\mathrm{CO}$, and that an application of $\mathrm{LTC}_{4}$ or $\mathrm{PGE}_{2}$ with $\mathrm{AA}$ is a useful method for differential evaluation of these inhibitors.
\end{abstract}

Keywords: Arachidonic acid-induced ear edema, Prostaglandin $\mathrm{E}_{2}$, Leukotriene $\mathrm{C}_{4}$, Indomethacin, Zileuton

It is well established that prostaglandins (PGs), cyclooxygenase (CO) products of arachidonic acid (AA), are involved in inflammatory reactions as important inflammatory mediators, and inhibitors of PG biosynthesis have been developed as non-steroidal anti-inflammatory drugs. Recently, it has been shown that leukotrienes (LTs), 5lipoxygenase (5-LO) products of AA, are also involved in inflammatory reactions as proinflammatory mediators. $\mathrm{LTC}_{4}$ and $\mathrm{LTD}_{4}$ cause edema together with increased microvascular permeability $(1,2)$, and $\mathrm{LTB}_{4}$ causes leukocyte chemotaxis $(3,4)$. These findings have prompted interest in developing dual inhibitors of 5- $\mathrm{LO}$ and $\mathrm{CO}$ as anti-inflammatory drugs.

Several experimental models of inflammation such as carrageenan-induced paw edema and AA-induced ear edema have been widely used for the discovery and evaluation of anti-inflammatory drugs. The carrageenan-induced paw edema in rats is known to be sensitive to $\mathrm{CO}$ in- hibitors, but not to 5-LO inhibitors $(5,6)$. On the other hand, the AA-induced ear edema in mice is known to be suitable for evaluating 5-LO inhibitors $(7-10)$, but the effects of $\mathrm{CO}$ inhibitors on ear edema are not consistent. It has been demonstrated that indomethacin, piroxicam and naproxen suppressed AA-induced ear edema (7, 9, $10)$, while aspirin, ibuprofen and naproxen failed to suppress it $(8,10)$. Griswold et al. (10) showed that the suppressive effect of indomethacin on ear edema may be mediated through a mechanism other than $\mathrm{CO}$ inhibition. Thus, the involvement of PGs in the AA-induced ear edema and the mechanism of the anti-inflammatory effect of $\mathrm{CO}$ inhibitors in ear edema are still unclear, and there is no simple animal model of inflammation for evaluating dual inhibitors of 5-LO and CO.

The aim of this study is to establish a useful method for evaluating inhibitors of 5-LO and/or $\mathrm{CO}$, and for differentially evaluating these inhibitors. We examined 
the effects of $\mathrm{CO}$ and/or 5-LO inhibitors on the ear edema induced by low and high doses of AA and the effect of a local application of $\mathrm{PGE}_{2}$ or $\mathrm{LTC}_{4}$ on their anti-inflammatory effects to clarify the involvement of PGs and LTs in the ear edema and to differentially evaluate these inhibitors.

\section{MATERIALS AND METHODS}

\section{Animals}

Male ICR mice and Wistar rats were obtained from Nihon Clea, Inc. (Tokyo) and Nihon SLC, Inc. (Hamamatsu), respectively. They were housed in temperature-controlled rooms $\left(23 \pm 2^{\circ} \mathrm{C}\right)$ with a 12-hr light-dark cycle, and they were allowed free access to food and water. The experiments were carried out at a room temperature of $23 \pm 2{ }^{\circ} \mathrm{C}$. The animals were randomly assigned to the treatment groups.

\section{Drugs}

The following drugs were used: zileuton, MK886 and BW755C were synthesized at Dainippon Pharmaceutical Co., Ltd. The other drugs were obtained from the following commercial sources: indomethacin, ketoprofen, phenidone, mepyramine maleate, dexamethasone and AA (Sigma, St. Louis, MO, USA); bromelain (Nacalai Tesque, Kyoto); $\mathrm{PGE}_{2}$ and $\mathrm{LTC}_{4}$ (Funakoshi, Tokyo); $\mathrm{PGE}_{2}$ RIA kit (DuPont/NEN, Wilmington, DE, USA); and $\mathrm{LTB}_{4}$ RIA kit (Amersham, Tokyo). Drugs were suspended in a $0.5 \%$ tragacanth solution for oral administration. In an in vitro test, drugs were dissolved in ethanol and diluted with the medium used. The doses of drugs described in this paper refer to the forms presented above.

\section{Biosynthesis of $\mathrm{PGE}_{2}$ and $\mathrm{LTB}_{4}$ in isolated rat peritoneal cells}

Rat peritoneal cells were obtained from the peritoneal cavity of male Wistar rats $(300-350 \mathrm{~g})$ that had been injected intraperitoneally with $50 \mathrm{ml} / \mathrm{kg}$ of $5 \%$ sterilized soluble starch solution containing 5\% bactopeptone 4 days before (11). The peritoneal exudate was centrifuged at $1,000 \times g$ for $5 \mathrm{~min}$. Contaminating erythrocytes were lysed by exposing the cell pellet to $0.2 \% \mathrm{NaCl}$ solution for $30 \mathrm{sec}$. The cells were washed with saline solution 3 times and then resuspended in modified Eagle's medium containing $10 \%$ calf serum to be a density of $2 \times 10^{7}$ cells $/ \mathrm{ml}$. The cell suspension $(0.9 \mathrm{ml})$ was incubated at $37^{\circ} \mathrm{C}$ for 1 $\mathrm{hr}$ after addition of a drug $(0.1 \mathrm{ml})$ that was dissolved in $3 \%$ ethanol. After cooling the tubes, $0.5 \mathrm{~N} \mathrm{HCl}(1 \mathrm{ml})$ and ethyl acetate $(1 \mathrm{ml})$ were added to the cell suspension $(1 \mathrm{ml})$. The cell suspension was shaken for $10 \mathrm{~min}$ and centrifuged at $1,700 \times \mathrm{g}$ for $10 \mathrm{~min}$. A $30-\mu \mathrm{l}$ aliquot of the ethyl acetate layer was removed and evaporated under reduced pressure. The residue was stocked at $-80^{\circ} \mathrm{C}$ for subsequent analysis of $\mathrm{PGE}_{2}$ and $\mathrm{LTB}_{4}$ levels by radioimmunoassay.

\section{AA-induced ear edema}

The method described by Young et al. (7) was used with minor modifications. Briefly, $20 \mu 1$ of the acetone solution of AA was applied to both the inner and outer surfaces of the right ears of mice $(20-23 \mathrm{~g})$. One hour later, the mice were killed by inhalation of $\mathrm{CO}_{2}$ gas. A circular tissue sample ( $5.5 \mathrm{~mm}$ in diameter) from each ear was removed with a metalic punch and weighed. In some experiments, mice were killed $0.5,1,1.5,2,3,4,5$ or $6 \mathrm{hr}$ after AA application. In some experiments to elucidate the involvement of PGs or LTs in the anti-inflammatory effects of test drugs, $\mathrm{PGE}_{2}(1 \mu \mathrm{g} / 20 \mu \mathrm{l} / \mathrm{ear})$ was topically applied to the right ears together with AA solution or $\mathrm{LTC}_{4}$ saline solution $(0.1 \mu \mathrm{g} / 10 \mu \mathrm{l} / \mathrm{ear})$ was intradermally administered to the right ears immediately after AA application. The left ears of mice served as the control. Drugs were orally administered to mice $1 \mathrm{hr}$ before AA application. The ear swelling rate was calculated according to the following equation. The anti-edematous effect of drugs was expressed as percent inhibition of the ear swelling compared with the vehicle control.

Ear swelling $(\%)=(a-b) / b \times 100$

a: weight of a right ear treated with AA

b: weight of a left ear untreated

\section{Statistical analyses}

Results are presented as means \pm S.E.M. and $\mathrm{IC}_{50^{-}}$ values. Statistical significance between groups was analyzed by Student's $t$-test and Duncan's multiple-range test. The $\mathrm{IC}_{50}$-value, the concentration that is necessary to obtain $50 \%$ inhibition of the responses, was determined from the best fit regression line of a dose-response curve.

\section{RESULTS}

Effect of drugs on $\mathrm{LTB}_{4}$ and $P G E_{2}$ biosynthesis in rat peritoneal cells

Zileuton and MK886 potently reduced the $\mathrm{LTB}_{4}$ level (mean LTB $_{4}$ level \pm S.E.M. in the matched control groups: $936 \pm 20 \mathrm{pg} / \mathrm{ml}$ and $1513 \pm 163 \mathrm{pg} / \mathrm{ml}$, respectively) in rat peritoneal cells with $\mathrm{IC}_{50}$-values of $0.20 \mu \mathrm{M}$ and $10.8 \mu \mathrm{M}$, respectively, but did not affect the $\mathrm{PGE}_{2}$ level even at a dose of $50 \mu \mathrm{M}$ (Table 1). On the other hand, indomethacin and ketoprofen reduced the $\mathrm{PGE}_{2}$ level (mean $\mathrm{PGE}_{2}$ level \pm S.E.M. in the matched control groups: $3248 \pm 170 \mathrm{pg} / \mathrm{ml}$ and $2597 \pm 114 \mathrm{pg} / \mathrm{ml}$, respectively) in the peritoneal cells with $\mathrm{IC}_{50}$-values of $0.51 \mu \mathrm{M}$ and $0.50 \mu \mathrm{M}$, respectively, but did not reduce the $\mathrm{LTB}_{4}$ 
Table 1. Effects of inhibitors of 5-LO and/or CO on biosynthesis of $\mathrm{LTB}_{4}$ and $\mathrm{PGE}_{2}$ in isolated rat peritoneal cells

\begin{tabular}{lcc}
\hline Drugs & $\begin{array}{c}\mathrm{LTB}_{4} \text { biosynthesis } \\
\mathrm{IC}_{50}(\mu \mathrm{M})\end{array}$ & $\begin{array}{c}\mathrm{PGE}_{2} \text { biosynthesis } \\
\mathrm{IC}_{50}(\mu \mathrm{M})\end{array}$ \\
\hline 5-LO inhibitor & & \\
Zileuton & 0.20 & $>50$ \\
MK-886 & 10.8 & $>50$ \\
CO inhibitor & & \\
Indomethacin & $>50$ & 0.51 \\
Ketoprofen & $>50$ & 0.50 \\
Dual (5-LO and CO) inhibitor & \\
BW755C & 2.83 & 36.4 \\
Phenidone & 2.36 & 37.2 \\
\hline
\end{tabular}

level up to $50 \mu \mathrm{M}$. BW755C and phenidone reduced both the levels of $\mathrm{LTB}_{4}$ and $\mathrm{PGE}_{2}$, and their effects on $\mathrm{LTB}_{4}$ level were 13-15 times more potent than those on $\mathrm{PGE}_{2}$ level (Table 1).

Dose-response and time-course of $A A$-induced ear edema

A topical application of AA $(0.025-2.0 \mathrm{mg} / \mathrm{ear})$ to mouse right ear caused edema dose-dependently; ear edema was observed at doses over $0.05 \mathrm{mg} / \mathrm{ear}$, and it was maximal at $1 \mathrm{mg} /$ ear (Fig. 1). The values of the mean weight and standard error of mouse AA-treated right and untreated left ears were $8.7 \pm 0.59 \mathrm{mg}$ and $6.5 \pm 0.13 \mathrm{mg}$, respectively, for $0.05 \mathrm{mg} /$ ear of $\mathrm{AA}$; and they were $16.2 \pm 0.28 \mathrm{mg}$ and $6.3 \pm 0.14 \mathrm{mg}$, respectively, for 1 $\mathrm{mg} / \mathrm{ear}$ of AA.

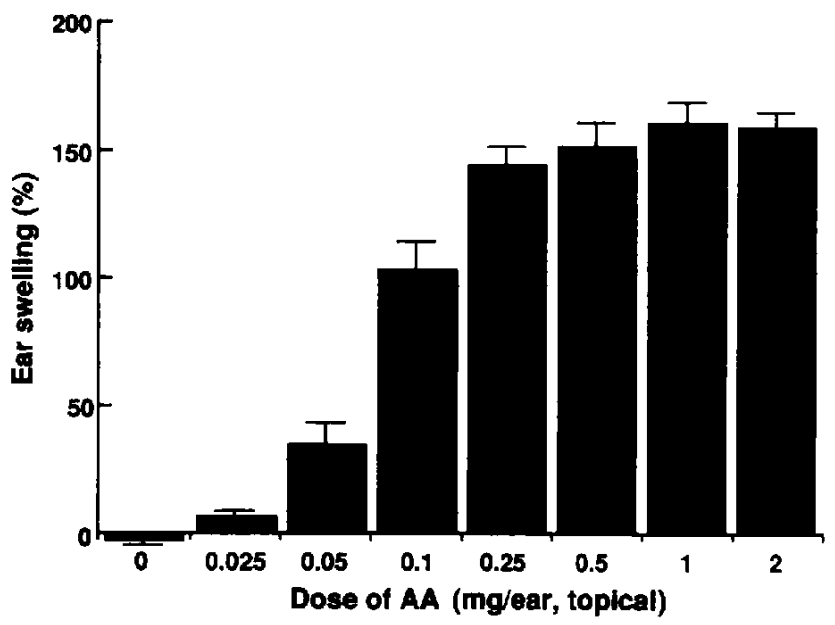

Fig. 1. Dose-response relationships for AA-induced ear edema in mice. Various doses $(0.025-2.0 \mathrm{mg} / 20 \mu \mathrm{l} / \mathrm{ear})$ of AA dissolved in acetone were topically applied to the right ears of mice. One hour later, a circular portion of the ear was punched out and weighed. Each value represents the mean \pm S.E.M. of 8 mice. Calculation of ear edema (\%): see Methods.

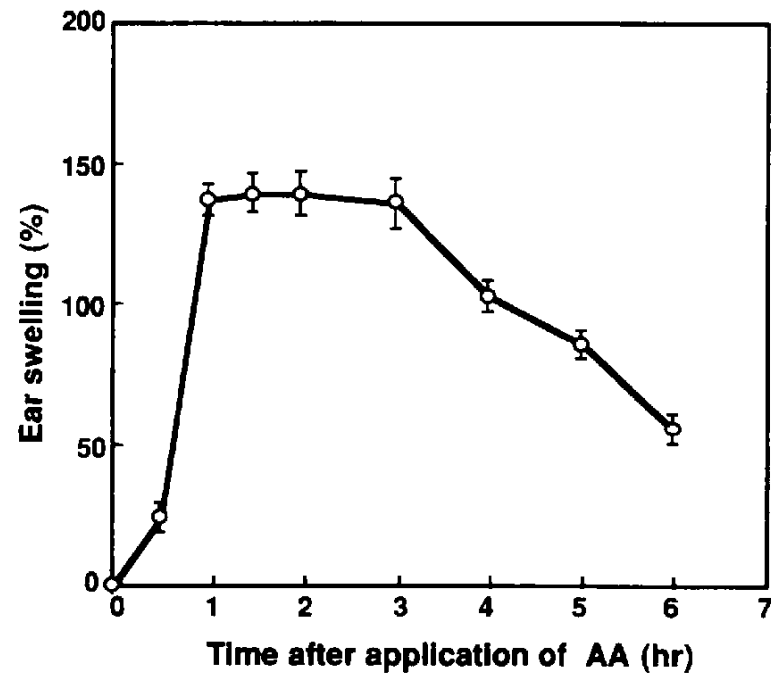

Fig. 2. Time-course of AA-induced ear edema in mice. AA $(0.25$ $\mathrm{mg} /$ ear) dissolved in acetone was topically applied to the right ears of mice. Each value represents the mean \pm S.E.M. of 8 mice. Calculation of ear edema $(\%)$ : see Methods.

AA $(0.25 \mathrm{mg} /$ ear)-induced ear edema almost reached the maximum at $1 \mathrm{hr}$ after AA application (Fig. 2), and the effect lasted for $2 \mathrm{hr}$. $\operatorname{LTC}_{4}(0.1 \mu \mathrm{g})$, when intradermally administered immediately after AA $(0.25 \mathrm{mg})$ application, did not enhance the ear edema (ear swelling: $143 \pm 5.0 \%$ for AA alone and $148 \pm 7.0 \%$ for AA plus $\left.\mathrm{LTC}_{4}\right)$ and neither did $\mathrm{PGE}_{2}(1 \mu \mathrm{g})$ concomitantly applied with AA (ear swelling: $128 \pm 5.0 \%$ for $\mathrm{AA}$ alone and $129 \pm 7.0 \%$ for $A A$ plus $P G_{2}$ ). An intradermal administration of $\mathrm{LTC}_{4}(0.1 \mu \mathrm{g})$ caused ear edema (ear swelling: $66 \%$ ) more potently than that of saline (ear swelling: $23 \%$ ), while a topical application of $\mathrm{PGE}_{2}(1 \mu \mathrm{g})$ did not cause it (ear swelling: 5\%).

Effects of zileuton and indomethacin on $A A(0.25$ and 2 $m g$ )-induced ear edema

The effects of zileuton and indomethacin on ear edema induced by $0.25 \mathrm{mg}$ and $2 \mathrm{mg}$ of AA were compared. As shown in Fig. 3, zileuton and indomethacin at $20 \mathrm{mg} / \mathrm{kg}$, p.o. suppressed ear edema induced by $0.25 \mathrm{mg}$ of AA, but not by $2 \mathrm{mg}$ of AA. Zileuton and indomethacin at 40 $\mathrm{mg} / \mathrm{kg}$, p.o. suppressed AA ( $0.25 \mathrm{mg})$-induced ear edema more potently than AA ( $2 \mathrm{mg})$-induced ear edema. The $0.25 \mathrm{mg} /$ ear dose of AA was chosen for the following experiments.

Effect of various drugs on $A A(0.25 \mathrm{mg})$-induced ear ede$m a$

As shown in Fig. 4, zileuton ( 40 and $80 \mathrm{mg} / \mathrm{kg}$, p.o.), a 5-LO inhibitor, and MK886 (640 mg/kg, p.o.), an inhibitor of 5-lipoxygenase activating protein (FLAP), dose- 

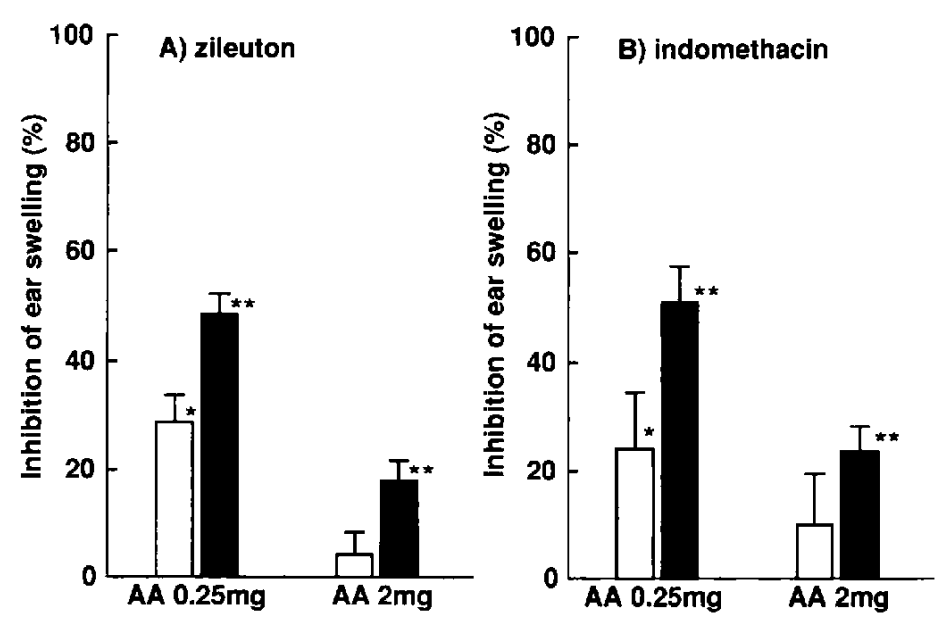

Fig. 3. Effect of zileuton (A) and indomethacin (B) on mouse ear edema induced by $0.25 \mathrm{mg}$ and $2 \mathrm{mg}$ of AA. Drugs were orally administered to mice at $1 \mathrm{hr}$ before AA application. The effect of drugs was expressed as percent inhibition of the ear swelling compared with the vehicle control. Each value represents the mean \pm S.E.M. of 7 mice. A) Open and closed columns: 20 and 40 $\mathrm{mg} / \mathrm{kg}$ of zileuton, respectively. B) Open and closed columns: 20 and $40 \mathrm{mg} / \mathrm{kg}$ of indomethacin, respectively. ${ }^{*} \mathrm{P}<0.05$ and ${ }^{* *} \mathrm{P}<0.01$, significantly different from the vehicle control.
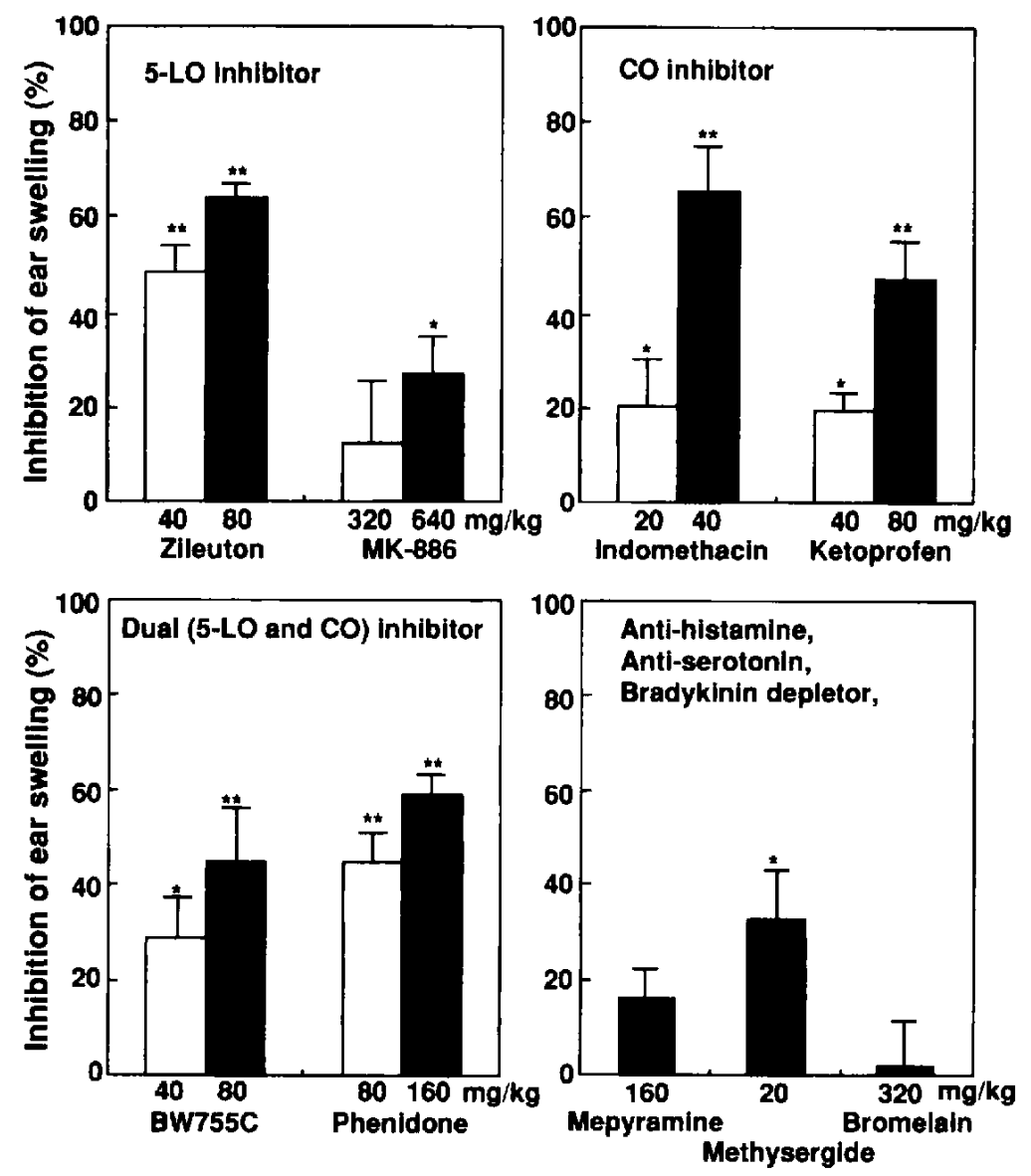

Fig. 4. Effect of drugs on AA-induced ear edema in mice. Drugs were orally administered to mice $1 \mathrm{hr}$ before AA (0.25 mg) application. The effect of drugs was expressed as percent inhibition of the ear swelling compared with the vehicle control. Each value represents the mean \pm S.E.M. of $7-8$ mice. ${ }^{*} \mathrm{P}<0.05$ and ${ }^{* *} \mathrm{P}<0.01$, significantly different from the vehicle control. 
dependently suppressed the ear edema. MK886 was less potent than zileuton in suppressing the ear edema. Indomethacin (20 and $40 \mathrm{mg} / \mathrm{kg}$, p.o.) and ketoprofen ( 40 and $80 \mathrm{mg} / \mathrm{kg}, \mathrm{p.o}$.), $\mathrm{CO}$ inhibitors, BW755C (40 and 80 $\mathrm{mg} / \mathrm{kg}$, p.o.) and phenidone ( 80 and $160 \mathrm{mg} / \mathrm{kg}$, p.o.), 5-LO and $\mathrm{CO}$ dual inhibitors, also suppressed the ear edema. Methysergide ( $20 \mathrm{mg} / \mathrm{kg}$, p.o.), a serotonin antagonist, suppressed the ear edema by $35 \%$, while mepyramine $(160 \mathrm{mg} / \mathrm{kg}, \mathrm{p} . \mathrm{o}$.$) , a histamine antagonist, and$ bromelain ( $320 \mathrm{mg} / \mathrm{kg}$, p.o.), a bradykinin depletor, did not.
Influence of $\mathrm{PGE}_{2}$ and $\mathrm{LTC}_{4}$ on the anti-edematous effects of 5-LO and/or $\mathrm{CO}$ inhibitors in AA-induced ear edema

As shown in Fig. 5, a topical application of $\mathrm{PGE}_{2}(1$ $\mu \mathrm{g}$ /ear) to mouse ear markedly reduced the suppressive effect of indomethacin $(40 \mathrm{mg} / \mathrm{kg}, \mathrm{p} . \mathrm{o}$.) and ketoprofen ( $80 \mathrm{mg} / \mathrm{kg}$, p.o.) on AA-induced ear edema, but did not reduce those of zileuton $(80 \mathrm{mg} / \mathrm{kg}, \mathrm{p} .0$.$) , MK886 (640$ $\mathrm{mg} / \mathrm{kg}, \mathrm{p} .0$.$) , BW755C ( 80 \mathrm{mg} / \mathrm{kg}, \mathrm{p.o.})$ and phenidone $(160 \mathrm{mg} / \mathrm{kg}, \mathrm{p} . \mathrm{o}$.$) . On the other hand, an intradermal ap-$ plication of $\mathrm{LTC}_{4}(0.1 \mu \mathrm{g} /$ ear $)$ reduced the anti-edema-
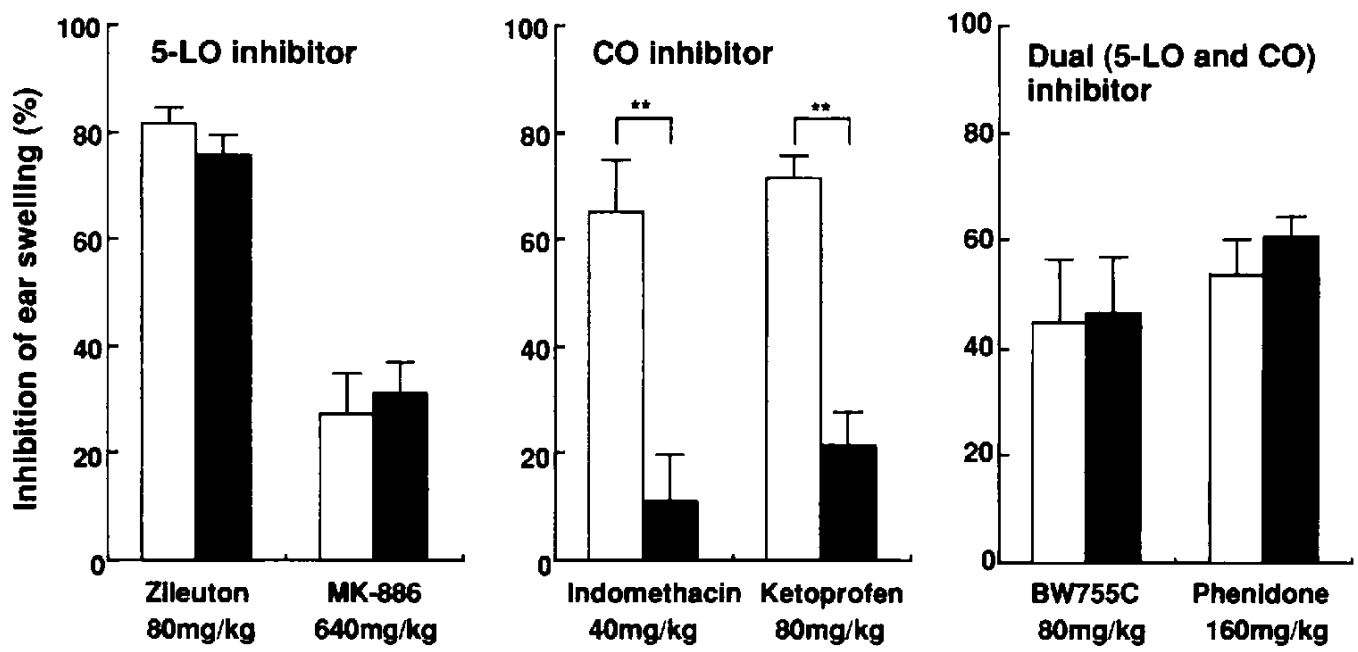

Fig. 5. Influence of $\mathrm{PGE}_{2}$ on anti-edematous effects of 5-LO and/or $\mathrm{CO}$ inhibitors in AA-induced ear edema in mice. $\mathrm{PGE}$ dissolved in acetone $(1 \mu \mathrm{g} / 20 \mu \mathrm{l} / \mathrm{ear})$ was topically applied together with AA to the right ears of mice. Drugs were orally administered to rats $1 \mathrm{hr}$ before $\mathrm{AA}$ application. Each value represents the mean \pm S.E.M. of 8 mice. ${ }^{* *} \mathrm{P}<0.01$. Open column: AA-induced edema, Closed column: AA plus $\mathrm{PGE}_{2}$-induced edema.
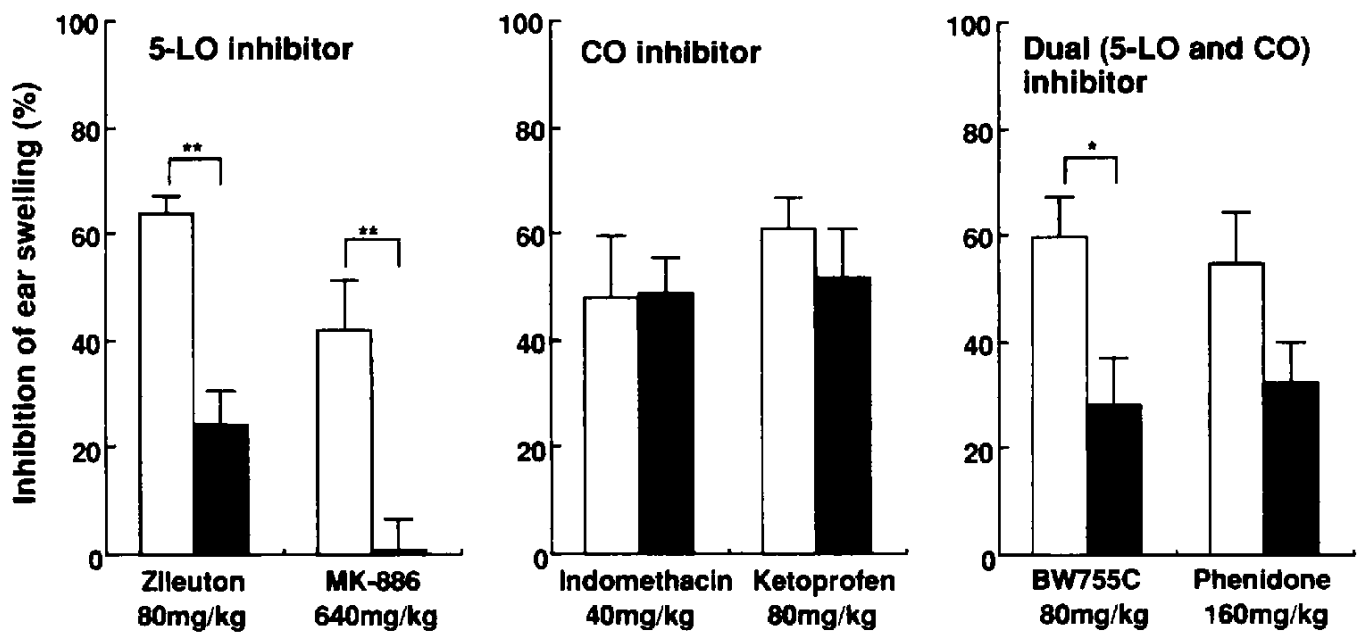

Fig. 6. Influence of $\mathrm{LTC}_{4}$ on anti-edematous effects of 5-LO and/or $\mathrm{CO}$ inhibitors in AA-induced ear edema in mice. $\mathrm{LTC}_{4}$ dissolved in saline $(0.1 \mu \mathrm{g} / 10 \mu \mathrm{l} / \mathrm{ear})$ was intradermally injected into the right ears of mice immediately after AA application. Drugs were orally administered to mice $1 \mathrm{hr}$ before AA application. Each value represents the mean \pm S.E.M. of $8 \mathrm{mice}$. ${ }^{*} \mathbf{P}<0.05,{ }^{* *} \mathbf{P}<0.01$. Open column: AA-induced edema, Closed column: AA plus $\mathrm{LTC}_{4}$-induced edema. 
tous effect of zileuton, phenidone and BW755C in the model, and it completely abolished that of MK886. However, an intradermal application of $\mathrm{LTC}_{4}$ did not reduce those of indomethacin and ketoprofen (Fig. 6).

\section{DISCUSSION}

The present study showed that a topical application of AA to mouse ear caused ear edema dose-dependently, and that the $0.25 \mathrm{mg}$ dose of AA exerted the maximal edema of the ear. At this dose of AA, both the PG and LT mechanisms must be fully operating in inducing edema, since $\mathrm{PGE}_{2}(1 \mu \mathrm{g} / \mathrm{ear})$ and $\mathrm{LTC}_{4}(0.1 \mu \mathrm{g} / \mathrm{ear})$, which enhance mutually the AA-induced ear edema in mice (8), did not enhance the ear edema. The AA $(0.25 \mathrm{mg})$ dose used for evaluating the 5-LO and/or $\mathrm{CO}$ inhibitors in the present study was 8 times less than the dose $(2 \mathrm{mg} / \mathrm{ear})$ used in the previous reports $(8-10)$. In the present study, zileuton and indomethacin at $20 \mathrm{mg} / \mathrm{kg}$ suppressed ear edema induced by $0.25 \mathrm{mg}$ of AA, but not that by $2 \mathrm{mg}$ of AA. Accordingly, the anti-edematous effects of inhibitors of 5-LO and $\mathrm{CO}$ can be detected more sensitively under our conditions.

Before the effects of $\mathrm{CO}$ and/or 5-LO inhibitors on the AA-induced ear edema in mice were examined, we confirmed the effects of these agents, especially dual inhibitors of $\mathrm{CO}$ and 5-LO, on $\mathrm{CO}$ and 5-LO activities of rat peritoneal exudate cells, as it has been demonstrated that there was little difference in the inhibition of leukotriene production by drugs such as MK886, zileuton and BW755C between mouse and rat peritoneal leukocytes (12). Zileuton (13), a 5-LO inhibitor, and MK886 $(14,15)$, a 5-LO activating protein inhibitor, markedly inhibited $\mathrm{LTB}_{4}$ biosynthesis, but did not inhibit $\mathrm{PGE}_{2}$ biosynthesis in rat peritoneal cells up to $50 \mu \mathrm{M}$. As well known, indomethacin and ketoprofen, $\mathrm{CO}$ inhibitors, markedly inhibited $\mathrm{PGE}_{2}$ biosynthesis, but did not inhibit $\mathrm{LTB}_{4}$ biosynthesis up to $50 \mu \mathrm{M}$. Phenidone (16) and BW755C (17), dual inhibitors of 5-LO and CO, were found to inhibit $\mathrm{LTB}_{4}$ biosynthesis $13-15$ times more potently than $\mathrm{PGE}_{2}$ biosynthesis.

Orally administered zileuton, MK886, phenidone and BW755C potently suppressed the AA-induced ear edema in mice. These results, being consistent with those of locally applied 5-LO inhibitors in AA-induced ear edema in mice $(7,9)$, support the findings that LTs are involved in AA-induced ear edema in mice. In addition, indomethacin and ketoprofen were found to markedly suppress the ear edema, although the higher doses of these drugs were necessary for suppressing the ear edema as compared with the doses at which these drugs exerted anti-inflammatory effects in other models (18). On the other hand, it has been demonstrated that $\mathrm{CO}$ inhibitors such as ibuprofen, aspirin and naproxen did not suppress the AA-induced ear edema in mice $(8,10)$. In the present study, indomethacin at $40 \mathrm{mg} / \mathrm{kg}$ suppressed ear edema induced by 0.25 mg of AA more potently than that induced by $2 \mathrm{mg}$ of AA. Young et al. (7) showed that naproxen suppressed ear edema induced by $0.5 \mathrm{mg}$ of AA, but failed to suppress ear edema induced by $2 \mathrm{mg}$ of AA. Therefore, the inconsistent effects of the $\mathrm{CO}$ inhibitors between their experiments and ours may be explained by the difference of AA dose used as described above. The high doses of mepyramine $(160 \mathrm{mg} / \mathrm{kg})$, a histamine antagonist, and bromelain $(320 \mathrm{mg} / \mathrm{kg})$, a bradykinin depletor, did not suppress the ear edema, while methysergide (a serotonin antagonist) at $20 \mathrm{mg} / \mathrm{kg}(19)$, suppressed it slightly. These results suggest that PGs as well as LTs are mainly involved in the AA-induced ear edema in mice, although serotonin may also partly contribute to it.

Griswold et al. (10) reported that indomethacin suppressed the AA-induced ear edema in mice and that its effect might be mediated through a mechanism other than $\mathrm{CO}$ inhibition. Thus, we examined the mechanism of the anti-inflammatory effect of indomethacin and zileuton in the AA-induced ear edema in mice. If indomethacin and zileuton suppress the ear edema through reducing the levels of endogenous PGs and LTs, respectively, exogenous supplementary PGs and LTs could reduce the anti-edematous effect of these drugs. In the present experiments, the suppressive effects of indomethacin and ketoprofen on the AA-induced ear edema were found to be reduced by a topical application of $\mathrm{PGE}_{2}(1 \mu \mathrm{g} / \mathrm{ear})$, which did not cause ear edema by itself, but not to be reduced by an intradermal administration of $\mathrm{LTC}_{4}(0.1 \mu \mathrm{g} / \mathrm{ear})$, which caused ear edema by itself. A topical application of $\mathrm{LTC}_{4}$ ( $1 \mu \mathrm{g} /$ ear) did not cause ear edema and did not reduce the suppressive effects of zileuton on the AA-induced ear edema, suggesting that $\mathrm{LTC}_{4}$ enough to cause ear edema was not absorbed from the skin. The results are in line with the findings that the suppressive effect of topically applied indomethacin on AA-induced ear edema in mice is abolished by concomitant application of $\mathrm{PGE}_{2}$ (9), and they suggest that their suppressive effects are mediated through the well-known CO inhibition. As it has been suggested that $\mathrm{PGE}_{2}$ causes vasodilatation, which is responsible for the potentiation of plasma exudation into tissues produced by other inflammatory mediators (20), the reduction of the anti-edematous effects of indomethacin and ketoprofen by $\mathrm{PGE}_{2}$, which did not cause ear edema by itself, may probably be due to the synergistic effect of $\mathrm{PGE}_{2}$ with LTs and serotonin. On the other hand, the suppressive effects of zileuton and MK886 on the AA-induced ear edema were reduced by $\mathrm{LTC}_{4}$, but not by $\mathrm{PGE}_{2}$. These results suggest that the suppressive effects of these drugs on the ear edema are mediated through the inhibi- 
tion of 5-LO. Reduction of the anti-edematous effects of zileuton and $\mathrm{MK} 886$ by $\mathrm{LTC}_{4}$ may be probably due to the increased vascular permeability caused by $\mathrm{LTC}_{4}$.

We demonstrated that inhibitors of 5-LO and/or $\mathrm{CO}$ are differentially evaluated by a local application of $\mathrm{LTC}_{4}$ or $\mathrm{PGE}_{2}$ with $\mathrm{AA}$. Using this method, we examined the anti-inflammatory effects of dual inhibitors and their mechanism. Phenidone and BW755C suppressed the AAinduced ear edema in mice, and their suppressive effects were reduced by $\mathrm{LTC}_{4}$, but not by $\mathrm{PGE}_{2}$. These results suggest that the anti-edematous effects of phenidone and BW755C are mediated through the inhibition of LT biosynthesis but not through the inhibition of PG biosynthesis.

In conclusion, our results suggest that AA $(0.25 \mathrm{mg})$-induced ear edema in mice is mediated mainly by LTs and PGs, and this is a suitable model for evaluating inhibitors of 5-LO and/or CO, and that a local application of $\mathrm{LTC}_{4}$ or $\mathrm{PGE}_{2}$ with $\mathrm{AA}$ makes the differential evaluation of inhibitors of 5-LO and/or CO possible.

\section{Aknowledgments}

We wish to thank Dr. J. Matsumoto and Dr. T. Karasawa for their helpful advice, and Dr. Y. Nishikawa for drug synthesis.

\section{REFERENCES}

1 Camp RDR, Coutts AA, Greaves MW, Kay AB and Walport MJ: Responses of human skin to intradermal injection of leukotrienes $\mathrm{C}_{4}, \mathrm{D}_{4}$ and $\mathrm{B}_{4}$. Br J Pharmacol 80, 497-502 (1983)

2 Peck MJ, Piper PJ and Williams TJ: The effect of leukotrienes $\mathrm{C}_{4}$ and $\mathrm{D}_{4}$ on the microvasculature of guinea-pig skin. Prostaglandins 21, 315-321 (1981)

3 Palmblad J, Malmsten CL, Udén A-M, Rádmark O, Engstedt $\mathrm{L}$ and Samuelsson B: Leukotriene $B_{4}$ is a potent and stereospecific stimulator of neutrophil chemotaxis and adherence. Blood 58, $658-661(1981)$

4 Czarnetzki BM and Mertensmeier R: In vitro and in vivo chemotaxis of guinea pig leukocytes toward leukotriene $B_{4}$ and its $\omega$-oxidation products. Prostaglandins 30, 5-11 (1985)

5 Flower R, Gryglewski R, Herbaczynska-Cedro K and Vane JR: Effects of anti-inflammatory drugs on prostaglandin biosynthesis. Nature New Biol 238, 104-106 (1972)

6 Higgs GA, Follenfant RL and Garland LG: Selective inhibition of arachidonate 5-lipoxygenase by novel acetohydroxamic acids: effects on acute inflammatory responses. $\mathrm{Br} \mathbf{J}$ Pharmacol 94, 547-551 (1988)

7 Young IM, Spires DA, Bedord CJ, Wagner B, Ballaron SJ and
De Young LM: The mouse ear inflammatory response to topical arachidonic acid. J Invest Dermatol 82, 367-371 (1984)

8 Inoue $\mathrm{H}$, Mori $\mathrm{T}$ and Koshihara $\mathrm{Y}$ : Sulfidopeptide-leukotrienes are major mediators of arachidonic acid-induced mouse ear edema. Prostaglandins 36, $731-739$ (1988)

9 Crummey A, Harper GP, Boyle EA and Mangan FR: Inhibition of arachidonic acid-induced ear oedema as a model for assessing topical anti-inflammatory compounds. Agents Actions 20, 69-76 (1987)

10 Griswold DE, Webb E, Schwartz L and Hanna N: Arachidonic acid-induced inflammation: Inhibition by dual inhibitor of arachidonic acid metabolism, SK\&F 86002 . Inflammation 11, $189-199$ (1987)

11 Ohuchi K, Kamada Y, Levine L, and Tsurufuji S: Glycyrrhizin inhibits prostaglandin $E_{2}$ production by activated peritoneal macrophages from rats. Prostaglandins Med 7, 457-463 (1981)

12 Fruchtmann R, Mohrs K-H, Hatzelmann A, Raddatz S, Fugmann $B$, Junge $B$, Horstmann $\mathbf{H}$ and Müller-Peddinghaus $\mathbf{R}$ : In vitro pharmacology of BAY X1005, a new inhibitor of leukotriene synthesis. Agents Actions 38, 188-195 (1993)

13 Carter GW, Young PR, Albert DH, Bouska J, Dyer R, Bell RL, Summers JB and Brooks DW: 5-Lipoxygenase inhibitory activity of zileuton. J Pharmacol Exp Ther 256, 929-937 (1991)

14 Rouzer CA, Ford-Hutchinson AW, Morton HE and Gillard JW: MK886, a potent and specific leukotriene biosynthesis inhibitor blocks and reverses the membrane association of 5-lipoxygenase in ionophore-challenged leukocytes. J Biol Chem 265, 1436- $1442(1990)$

15 Dixon RAF, Diehl RE, Opas E, Rands E, Vickers PJ, Evans JF, Gillard JW and Miller DK: Requirement of a 5-lipoxygenase-activating protein for leukotriene synthesis. Nature 343, 282-284 (1990)

16 Blackwell GJ and Flower RJ: 1-Phenyl-3-pyrazolidone: an inhibitor of arachidonate oxidation in lung and platelets. $\mathrm{Br} \mathbf{J}$ Pharmacol 63, 360P (1978)

17 Higgs GA, Flower RJ and Vane JR: A new approach to antiinflammatory drugs. Biochem Pharmacol 28, 1959- 1961 (1979)

18 Nakamura H, Yokoyama Y, Motoyoshi S, Ishii K, Imazu C, Seto $Y$, Kadokawa $T$ and Shimizu $M$ : The pharmacological profile of 2-(8-methyl-10,11-dihydro-11-oxodibenz[b,f]oxepin2-yl)propionic acid (AD-1590), a new non-steroidal anti-inflammatory agent with potent antipyretic activity. Arzneimittelforschung 33, 1555-1569 (1983)

19 Calhoun W, Yu J, Sung A, Chau TT, Marshall LA, Weichman BM and Carlson RP: Pharmacological modulation of D-49 phospholipase $A_{2}$-induced paw edema in the mouse. Agents Actions 27, 418-421 (1989)

20 Williams TJ and Peck MJ: Role of prostaglandin-mediated vasodilatation in inflammation. Nature 270, 530-532 (1977) 